\title{
1990-LUVUN TUTKIMUSPOLITIIKKA SISÄKUVASSA
}

JOHANNA HAKALA, ERKKI KAUKONEN, MIKA NIEMINEN \& OILI-HELENA YLIJOKI. (2003) Yliopisto - tieteen kehdosta projektimyllyksi?

Gaudeamus. 237 s.

Nykyajattelussa yliopisto ja tiede yhdistyvät toisiinsa saumattomasti. Ajatus yliopistosta tieteen kehtona on hellyttävä ja aseista riisuva. Omana aikanamme asettuminen tieteen tielle tarkoittaa jotakin vastaavaa kuin kirkon vastustaminen keskiajalla, joskin vastustajaan sovellettu rangaistusasteikko on toki noista ajoista lieventynyt. Tieteen siunauksellisuudesta tai välttämättömyydestä vallitsee kuitenkin vahva yksimielisyys ja yliopistoilla on ollut yksinoikeus määritellä, mikä oikein on tiedettä ja mikä tiedettä parhaiten edistää. Tuloksena on ollut yliopistotieteiden malli, jossa kustakin tieteenalasta on kehkeytynyt oma autonomiaansa puolustava, yhteismitattomuuttaan juhliva ja metodejaan hiova saarekkeensa. Kehdon sijaan kysymyksessä on ollut pikemminkin tehokkaasti ja yhä eriytyneemmin toimiva institutionalisoitunut hautomo. Akateemisen tiedontuotannon on nyt kuitenkin nähty tulleen tiensä päähän. Hakalan ym. tutkimus kuvaa muutosta yliopiston sisältä päin.

Teos lähtee liikkeelle perinteisen järjestyksen ja työnjaon murtumisesta tiedontuotannossa ja yliopiston kolmannen tehtävän muotoutumisesta. Onkin väitetty, että akateeminen kapitalismi ja tiedontuotannon uu- sin tapa vie kovaa vauhtia maan tieteen mertonilaisten ideaalien alta tai asettaa oman ideaalinsa niiden rinnalle. Tekijät ovatkin ottaneet tehtäväkseen selvittää, miten uudet yliopistoihin kohdistuneet odotukset ja paineet, erityisesti kansainvälistyminen, itse asiassa heijastuivat harjoitettuun tutkimustoimintaan sekä tutkijoihin 1990-luvulla.

Jos yliopistotutkimuksen muutosta halutaan ymmärtää hienosyisesti ja ottaa huomioon sen moninaisuus, lähtökohdaksi asettuu, että mitään yhdenmukaista akateemista tutkimusta ei ole olemassa, vaan yliopisto on heterogeeninen tieteenalakulttuurien ja organisatoristen ratkaisujen muodostama kokonaisuus (s. 23).

Tämä moninaisuus, jonka tutkijat ottavat omaksi lähtökohdakseen, kadottaen samalla yliopiston näköpiiristään, tarkoittaa sitä, että ympäristöstä nousevat muutospaineet kohdataan eri tavoin ja koetaan erilaisina eri osissa yliopistoa. Herääkin kysymys, mikä materiaalisesti oikein liittää yhteen ja yhdistää tieteenaloja. Mitä yliopisto on ylitse noiden tieteenalakulttuurien? Jakavatko ne muuta kuin tietyn menomomentin valtion budjetissa tai ovatko ne vain jonkin satunnaisen historiallisen oikun seurauksena pelaajia samassa kielipelissä, joka on yhtäältä niin löyhä, että siihen sopii mitä moninaisimpia pyrkimyksiä, mutta toisaalta taas niin sitova, että se saa nuo hankkeet näyttämään yhteismitallisilta?
TOIMINTAYMPÄRISTÖN PIIRTEITÄ 1990-LUVULLA

Ensimmäisenä tarkastelukohteena on yliopiston tiedepoliittinen toimintaympäristö 1990luvulla. Tuloksena syntyvä ajankuva on selkeä ja jäsentynyt. Yliopistollisten laitosten johtajien ( $n=369)$ näkökulmasta perustutkimus ei jäänyt soveltavan tutkimuksen jalkoihin, vaikka rahoitus muuttuikin hankekohtaiseksi ja määräaikaisina projektitutkijoina työskentelevien joukko kasvoi. Vastaajat olivat havainneet myös lievää tutkimuksen poikkitieteellistymistä tai tieteidenvälistymistä. Tutkijat toteavatkin olleensa lievästi yllättyneitä siitä, että hyvän tutkimuksen perusominaisuudet nähtiin kokolailla yhtäpitävästi. "Painotuserot tieteenalojen tutkijoiden käsityksissä viittaavat myös poikkeaviin tutkimustraditioihin ja -kulttuureihin sekä alojen yhteiskuntasuhteissa piileviin eroihin", he kuitenkin jatkavat (s. 64). Jos ei olisi odotettu eriytyviä tieteenalakulttuureja, niin juuri tämä yksimielisyys olisi noussut selitystä kaipaavaksi havainnoksi. Nyt painotuseroista pyritään tekemään kulttuureja konstituoivia piirteitä. Yliopistoissa tehtävä tutkimus näyttää tekijöiden mukaan säilyneen varsin tutkijalähtöisenä ja sisältäpäin määräytyneenä. Yksi yhteinen piirre on tutkimusryhmien yleistyminen myös perinteisesti yksilövetoisissa tieteissä. Taustalla on tekijöiden mukaan muutokset tutkimusrahoituksessa 
sekä yhteistyön suosiminen tutkimuspolitiikassa.

\section{TIETEENALAT OMANNÄKÖISIÄÄN}

Ruohonjuuritasoa valotetaan kolmen tapaustutkimuksen avulla. "Emme kuitenkaan tarkastele niinkään yksittäisten tutkijoiden kokemuksia vaan tutkijayhteisöissä jaettuja kulttuurisia jäsennyksiä. Edellisen luvun johtopäätökset osoittivat, että yliopistollisen tutkimuksen muutostrendit eroavat tieteenalaryhmittäin. Tämän takia on tärkeää paneutua yksityiskohtaisemmin eri tyyppisten tieteenalojen tutkimustoimintaan." (s. 97.) Itse olisin ollut taipuvainen kääntämään kelkan juuri päinvastaiseen suuntaan. Tekijät palauttavat kuitenkin mieleen sen, että yliopistotutkimus koostuu erilaisista tiedekulttuureista, jolloin on johdonmukaista ajatella, että ympäristön muutos tulkitaan eri tavoin eri kohdissa tutkimuksen kenttää. Havainnot on hankittu vanhempia, muutoksen läpikäyneitä tutkijoita $(n=23)$ haastattelemalla. "Siten haastatteluaineisto kertoo vuosikausia tai vuosikymmeniä tutkimustyötä tehneiden tutkijoiden käsityksistä ja kokemuksista" (s. 99).

Historiantutkijoiden puhe kuvaa hyvin tutkimusrahoituksessa vallitsevan markkinalogiikan raadollisuutta ja tutkimusta korruptoivaa vaikutusta, kun samalla päälle painaa kiristyvä tulosvastuu. Pintatieteen ja puolijohdetekniikan puolen tutkijat puolestaan näkivät olosuhteet asianmukaisiksi ja kokivat toimivansa tuotekehittelijöinä. He kuitenkin kaipasivat haihtunutta mahdollisuutta perustutkimuksen tekoon sekä itsenäisyyttä ja vapautta tutkimuk- sen teossa. Työ kaupallisuuden ja akateemisuuden ristivedossa ilmenee myös tasapainoiluna liikesalaisuuksien ja tulosten julkisuuden välillä. Työelämäntutkijat puolestaan edustavat itse tutkimusrahoituksensa hankkivaa, tutkimuksen (olosuhteiden pakosta?) kutsumuksena näkevää ryhmää. Rahoituksen hankkimisen ohella heiltä vaaditaan kykyä sovittaa yhteen erilaisia intressejä (akateemisuus - tilaajan toiveet) sekä luoda eri projektien ylitse ulottuvaa jatkuvuutta. He kaipaavat lähinnä vakautta työsuhteisiinsa ja uranäkymiä.

\section{YHDISTÄVIÄ PIIRTEITÄ}

Riippuvuus ulkoisen rahoituksesta, viranhaltijoiden aseman kurjistuminen ja projektitutkijoiden luokan synty, akateemisen työn proletarisoituminen, on tutkittuja yksiköitä yhdistävä piirre. Tästä huolimatta tekijät korostavat, että "[e]ri yksiköissä vallitsee selvästi toisista erottuva tieteenalakulttuuri omine ihanteineen, normeineen ja perususkomuksineen", mutta toteavat samalla, että "[t]ietyt perinteiset akateemiset arvot ja normit vallitsevat kuitenkin kaikissa tutkimissamme yksiköissä" (s. 144).

\section{KANSAINVÄLISET LAINEET HUUHTOVAT RANTAA}

Yliopisto muotoutui ylikansallisena instituutiona, kansallistui sittemmin ja pyrkii nyt kansainvälistymään. Kansainvälistyminen nousi tiedepoliittiseksi prioriteetiksi Suomessa 80-luvun lopulla. Tämä nähtiin edellytykseksi sille, että Suomi saattoi pienenä ja tutkimusresursseiltaan rajallisena maana pysyä kehityksessä mukana. Tutkimuksessa kartoitettiinkin myös laitosten johtajien näkemyksiä kansainvälistymisestä ja vallitsevia asenteita kansainvälistymiseen. Kansainvälistymisen merkityksestä oltiinkin hyvin yksimielisiä eikä eroja tieteenalojen välillä havaittu. Tekijät kuitenkin toteavat, että "on luultavaa, että vastaajilla on esimerkiksi tieteenalan mukaan erilaisia näkemyksiä siitä, mitä kansainvälisyys itse asiassa tarkoittaa ja mikä tekee siitä tärkeän" (s. 154). Tämä pätenee jokaiseen. Kyselyn valossa perinteisesti kansallisiksi mielletyt tieteenalat ovat kansainvälistyneet ja kansainvälistymisestä on tullut aikaisempaa tulosorientoituneempaa. Puolet vastaajista oli joko jokseenkin tai täysin eri mieltä väitteen "EU:n ohjelmat suuntaavat myönteisesti alan tutkimustoimintaa" kanssa. Näiden ohjelmien lähtökohdat koettiin yleisesti tieteen kannalta ongelmallisiksi.

Yhteenvedossa tekijät näkevät sekä muutoksen (projektimaisuus, ulkopuolinen rahoitus, soveltavuus) että pysyvyyden (tieteentekemisen perinteiset standardit) luonnehtivan yliopistollista tutkimusta. He toteavat, että "[y]leinen muutosprosessi ei myöskään ole valanut tieteenaloja samaan muottiin tai kuihduttanut niiden välisiä eroja. Vaikka samansuuntaisia muutoslinjoja on havaittavissa läpi koko yliopiston..., tarkemmin eriteltyinä eri tieteenalat ja tieteenalaryhmät poikkeavat silti selvästi toisistaan niin organisaatioltaan, toimintatavoiltaan kuin arvoiltaankin." (s. 193). Havainnoista ei ollut tässä tapauksessa horjuttamaan tekijöiden uskoa enemmän erojen kuin yhtäläisyyksi- 
en kukoistamiseen yliopistoinstituutioissa. He kokoavat lopuksi neljä erilaista tutkimusorientaatiota (akateeminen, markkinasuuntautunut, hallinnollinen ja kansalaisyhteiskunnallinen). Tekijät näkevät tutkimustyön jäsentyvän tasapainoiluna niiden välisissä ristivedoissa, pohtivat projektitutkimuksen seuraamuksia ja kartoittavat yliopistollisen tutkimuksen tulevaisuutta. Perusongelmana on, miten vapauttaa tutkimustyötä tekevät tutkijat yksilötasolla niin, että vapautumisen kustantavat tahot voivat olla varmoja siitä, että he samalla saavat panokselleen parhaan vastineen.

Liitteessä 1 tutkijat tuovat esiin ongelmat laitosten luokittelussa eri tieteenaloihin. Heidän mukaan eri alojen substanssia tuntemattomalla henkilöllä on tässä vaikeuksia. Ehkäpä aineiston olisi voinut antaa luokittua eli rakentaa ryhmät tilastollisen analyysin avulla. Kuva tieteenalakulttuureista olisi saattanut näyttää "luonnottomalta", mutta tällöin olisi vältetty ongelma, joka syntyy siitä, että vallitseva tieteenala- jako otetaan "luonnollisena" ja kulttuurisena.

Aikaansaannos on kokonaisuutena sujuva, asiapitoinen, ajankohtainen ja hyvin etenevä kuvaus tiede- ja tutkimuspoliittisen ympäristön muutoksesta yliopiston sisältä nähtynä. Se kytkeytyy monipuolisesti yliopiston tilanteesta ja sen tulevaisuudesta käytyyn keskusteluun ja valottaa asiaa tutkimustoiminnan käytännön kautta. Kuvaavaa on, että tutkimus on syntynyt Suomen Akatemian rahoittamana projektityönä. Mistään ei kuitenkaan suoranaisesti ilmene, miten ne ristivetoisuudet, joita tämä tutkimusprojekti tuo esiin, todentuivat sen itsensä kohdalla. Lopputulos on laadukas ja varman päälle tehty. Olisin kuitenkin toivonut siltä ripausta originaalisuutta. Ehkä juuri riskittömyys ja yllätyksettömyys on ominaista projektitutkimukselle.

\section{YLIOPISTO OSAKSI ASIANTUNTIJAVALTAA}

Yliopistoa, jolla olisi korvaamaton tehtävänsä osana kansalaisyhteiskuntaa ja jota kansa- laiset olisivat valmiit puolustamaan (ja myös rahoittamaan) meidän yliopistona, ei ole eikä todennäköisesti tule. Yliopisto on vieraantunut kansalaisyhteiskunnasta samalla kun se on tullut yhä elimellisemmäksi osaksi asiantuntijavaltaa ja sen ekspansiota. Kansalaisten vieraantuminen, eksperttiyden alojen keskinäinen kilpailu ja tieteenharjoittamisen muuttuminen työnjaon ja luokkarakenteen leimaamaksi tiedontuotannoksi tarkoittaa sitä, ettei kukaan koe yliopistoa omakseen. Tätä vahvistaa edelleen se, että tutkijat kiinnittävät huomionsa tieteenalakulttuurien eroihin, luovat havaitsemiensa erojen pohjalta heimoja ja alleviivaavat näin eroavuuksia jaettujen ja toimijoita yhdistävien piirteiden kustannuksella. Tilanne on vastaava kuin viime vuosisadan alussa, jossa psykologiaa konstituoiva kysymys koski ihmisryhmiä erottavia, ei ihmisiä yhdistäviä piirteitä. Kun vaihtoehtoista historiaa ei ole, voimme vain arvailla ratkaisun seuraamuksia.

Vesa Huotari 